\title{
LA INFLUENCIA DEL DERECHO DE FAMILIA EN LA POSICIÓN DEL CÓNYUGE SUPÉRSTITE EN EL ORDEN DE LLAMAMIENTOS EN LA SUCESIÓN $A B$ INTESTATO: EVOLUCIÓN HISTÓRICA
}

\author{
Alfonso Murillo Villar \\ Doutor em Direito. Professor Catedrático de Derecho \\ Romano da Universidad de Burgos (Espanha).
}

RESUMEN: Este trabajo, soslayando cualquier otra pretensión genérica, se ciñe exclusivamente al análisis de un tema muy puntual pero grandemente revelador, cual es la influencia y repercusión del derecho de familia en el orden de llamamientos establecido por la ley en los supuestos de sucesión $a b$ intestato. Y todo ello, desde el origen romano de la sucesión intestada hasta las más recientes legislaciones del derecho español, tanto común como foral o autonómico. Con ciertos altibajos, la situación del cónyuge supérstite o del conviviente en unión estable de pareja ha ido mejorando ("escalando puestos") de forma progresiva, hasta el punto de que en las más recientes legislaciones se antepone su llamamiento al de los ascendientes del causante y se coloca inmediatamente después de los descendientes. Estamos, pues, ante un caso muy evidente de cómo la evolución del derecho de familia, su concepto, incide directamente en el derecho sucesorio.

PALABRAS-CLAVE: Derecho de familia; Sucesión intestada; Orden de llamamientos; Cónyuge viudo.

\section{A influência do Direito de Família na posição do cônjuge supérstite na ordem de chamamento na sucessão ab intestato: evolução histórica}

RESUMO: Este trabalho, evitando qualquer outra reivindicação genérica, limita-se exclusivamente à análise de um tópico muito específico, mas muito revelador, que é a influência e repercussão do direito da família na ordem de chamamento estabelecido pela lei em casos de sucessão $a b$ intestato. E tudo isso, desde a origem romana da sucessão intestada até as legislações mais recentes da lei espanhola, tanto comuns como regionais ou autônomas. Com certos altos e baixos, a situação do cônjuge ou parceiro sobrevivente em um casal estável melhorou ("escalando posições"), ao ponto de que, na legislação mais recente, o seu chamamento preceda aos antepassados do falecido e é colocado imediatamente após os descendentes. Estamos, então, diante de um caso muito óbvio de como a evolução do Direito da Família, seu conceito, afeta diretamente o direito à herança.

PALAVRAS-CHAVE: Direito da família; Sucessão intestada; Ordem de chamamento; Cônjuge viúvo.

\section{The influence of Family Law in the position of the superstite spouse in the order of heirs in} the ab intestato succession: historical evolution

ABSTRACT: This study, laying aside any generic pretensions, limits itself exclusively to the analysis of a very specific, but immensely revealing topic, which is the influence and the repercussion of Family Law on the order of heirs, established in law for the circumstances of ab intestato inheritance. All of it, from Roman law on inheritance with no will up until more recent 
La influencia del Derecho de Familia en la posición del cónyuge supérstite en el orden de llamamientos en la sucesión ab intestato: evolución histórica

legislation in Spanish law, both in common and 'foral' or regional law. With a number of ups and downs, the situation of the surviving spouse or partner in a stable couple union has been improving ("moving up the social order") in a progressive way, to the point where in the most recent legislation its position in the order precedes the ascendants of the deceased and is placed immediately after the descendents. We therefore have a very evident case of how the evolution of Family Law, in conceptual terms, directly impacts on inheritance law.

KEYWORDS: Family law; Inheritance with no will; Order of heirs; Widow.

\section{INTRODUCCIÓN}

Pasarán muchos años hasta que se consiga que la Unión Europea unifique su derecho de sucesiones; es más, ni tan siquiera a día de hoy hay intentos serios y rigurosos por buscar una verosímil armonización. Sin embargo, sí que se está llevando a cabo en otros ámbitos jurídicos, fundamentalmente de derecho contractual, y las razones no son precisamente porque las transmisiones mortis causa no tengan su repercusión en el derecho patrimonial ${ }^{1}$. Aplicable desde el 17 de agosto de 2015 tenemos el Reglamento (UE) nº 650/2012 del Parlamento Europeo y del Consejo, de 4 de julio de 2012, relativo a la competencia, la ley aplicable, el reconocimiento y la ejecución de las resoluciones, a la aceptación y la ejecución de los documentos públicos en materia de sucesiones mortis causa y a la creación de un certificado sucesorio europeo. Pero es obvio que no es suficiente, aunque viene a cubrir el vacío existente hasta el momento en la materia, que ciertamente requiere soluciones habida cuenta de la cada vez más frecuente movilidad geográfica en nuestra sociedad actual ${ }^{2}$. Por otro lado, resulta innegable que la evolución del derecho de familia ${ }^{3}$, en el que las aproximaciones jurídicas entre ordenamientos europeos son mayores, incide directamente en el derecho sucesorio. No es nuestro objetivo abarcar a nivel internacional la influencia del derecho de familia en el derecho de sucesiones; sencillamente, vamos a buscar su incidencia, desde una perspectiva histórica, en un campo muy acotado cual es la posición del cónyuge supérstite en la sucesión ab intestato; el lugar que ocupa en el orden de llamamientos establecido por la ley.

Vamos a estudiar cómo la posición del cónyuge supérstite se ha ido robusteciendo en el orden de llamamientos, "escalando puestos", si se nos permite esta expresión, frente a otros colaterales. Y siempre como consecuencia de la evolución del concepto de familia y especialmente del derecho matrimonial. De ahí la imparable tendencia en favor de una mejoría de la posición del cónyuge viudo en el orden de prelación de la sucesión intestada. Por ello, no es difícil compartir la opinión de quien sostiene que el derecho sucesorio vertical ha mutado hacia un derecho sucesorio horizontal en el que los derechos de los hijos retroceden en beneficio del cónyuge ${ }^{4}$. Estamos, pues, ante un ejemplo palmario de cómo en la sucesión influye claramente el cariño familiar, el afecto así como la reducción conceptual de la idea de familia.

En este orden de cosas, es preciso apuntar que las necesidades de las familias van cambiando. Estamos ante nuevas necesidades, ante nuevos retos sociales a los que es preciso buscarles una repuesta diferente. Y ello porque actualmente conviven familias de características muy

1 Vid. S. Cámara Lapuente, «¿Derecho europeo de sucesiones? Un apunte», en Cámara Lapuente, (coord.), Derecho Privado Europeo, Madrid, Colex, 2003, pp. 1185 ss.

2 S. Valverde Martínez, «La unificación del derecho sucesorio europeo», en Economist \& Jurist, Difusión Jurídica y Temas de Actualidad, S.L., (21), nº 168, 2013, pp. 74 ss.

3 Muy sugerente el artículo de J.A. García Amado, «La familia y su derecho», en Diálogos Jurídicos 2016, (1). Anuario de la Facultad de Derecho de la Universidad de Oviedo, pp. 15 ss.

4 W. PINTENS, «Die Europäisierung des Erbrechts», en Zeitschrift für Europäisches Privatrecht (ZEuP) 3, 2001, pp. 629 ss. 
diversas, tanto, que han originado formas inesperadas. Superada la familia extensa, típica de las sociedades agrarias, en favor de la familia nuclear-conyugal, propia de la sociedad urbana e industrial, comienzan a eclosionar tipologías distintas. Es lo que podría denominarse familias postmatrimoniales en las que el vínculo conyugal no existe o es muy frágil e inestable. Serían las familias unipersonales (solteros, divorciados o viudos); monoparentales o matrifocales (madres sin pareja con hijos a su cargo, ya sean solteras o separadas); familias reconstituidas (parejas de segundas o posteriores nupcias con hijos procedentes de uniones anteriores) y familias de cohabitantes, uniones informales de pareja sin legalizar, con o sin hijos. A ello es menester apostillar que el matrimonio actual se caracteriza por una radical simetría igualitaria entre sus miembros. Y que hay nuevos patrones de convivencia (parejas no casadas, homo y heterosexuales) en los que prima la fidelidad y la lealtad. Es decir, el hecho familiar es absolutamente heterogéneo y resulta totalmente desacertado hablar, desde un punto de vista institucional, de un modelo único de familia cuando la realidad demuestra la coexistencia de varios modelos diferentes de familias ${ }^{5}$. Por tanto, la nueva realidad fruto de la transformación social es lógico que tenga su reflejo en el derecho sucesorio.

En este trabajo prescindimos de analizar la evolución de los derechos del cónyuge viudo en la sucesión intestada, campo en el que también se percibe una meridiana evolución, para centrarnos exclusivamente en la prelación de llamamientos ab intestato sin que ello signifique en modo alguno que en todos los casos pueda ser designado heredero el cónyuge supérstite. Es más, lo normal es que salvo situaciones excepcionales no lo sea nunca, que no le alcance el llamamiento en razón del lugar que ocupa en los órdenes sucesorios, lo cual no significa que no perciba otros derechos del causante que le puedan facilitar el vivir conforme a su estado anterior. No descartamos su estudio en el futuro, pero razones de espacio nos obligan a prescindir de ello en este momento. Nos referimos al estudio de la adjudicación de la quarta de la viuda pobre o quarta uxoria, a la cuota viudal, cuarta marital, cuota usufructuaria, usufructo viudal, usufructo universal, cuota legitimaria, etc..

\section{Desarrollo}

En el preámbulo de la Ley 10/2008, de 10 de julio, relativo a las sucesiones, en virtud de la cual se crea el libro cuarto del Código Civil de Cataluña, en el apartado V relativo a la Sucesión intestada, se reconoce abiertamente que "a efectos de la sucesión por causa de muerte, lo que es relevante es la existencia de una comunidad de vida estable y los lazos de afecto entre quienes conviven como pareja, y no el carácter institucional del vínculo que los une". Es decir, estamos ante cambios tan evidentes en materia sucesoria, que ponen de manifiesto cómo la evolución de la familia, su concepto, ha influido tanto que hasta ha motivado que se prescindiera de lo regulado en el Código de Sucesiones catalán de 1991, y cómo se ha aprovechado para introducir algunos cambios y actualizaciones. En definitiva, por encima de otros valores, prima la convivencia y el afecto ${ }^{6}$. Uno de estos cambios, a nuestro entender muy elocuente y al cual dedicamos este estudio, es ver como a lo largo de la historia el cónyuge viudo ha mejorado sustancialmente su posición en el orden de llamamientos que efectúa el legislador cuando nos hallamos ante una sucesión ab intestato. De hecho, actualmente en derecho catalán el cónyuge supérstite es llamado

5 Vid. F. Rivero HeRnÁnDEZ, «Panorama general de la reforma del derecho de familia en el Libro II del Código Civil de Cataluña», en GINÉs CASTELlET, (coord.) La familia del siglo XXI. Algunas novedades del Libro II del Código Civil de Cataluña, Barcelona, BOSCH EDITOR, 2011, pp.19 ss.

$6 \mathrm{M}^{\mathrm{a}} \mathrm{C}$. GeTE-Alonso y CALERA, «La sucesión intestada incorporada al Código Civil de Catalunya (principios-innovaciones)», en El nou dret successori del codi civil de Catalunya: materials de les Quinzenes Jornades de Dret Català a Tossa, Tossa de Mar, 25 i 26 de setembre de 2008, 2009, pp. 209-261. 
La influencia del Derecho de Familia en la posición del cónyuge supérstite en el orden de llamamientos en la sucesión ab intestato: evolución histórica

en segundo lugar, tras los hijos o sus descendientes si estos concurrieran por derecho de representación (Artículo 442-1 CCCat.).

Es obvio que el legislador catalán ha estado muy atento a la realidad social, no sólo por recoger y contemplar las nuevas situaciones de convivencia de relaciones de hecho y el matrimonio entre parejas del mismo sexo, sino y muy especialmente por atender de un modo tan particular a las relaciones afectivas que unen a las personas que deciden convivir durante buena parte de su existencia, primando los criterios de afectividad sobre otros como pueden ser la consanguinidad o los lazos familiares agnaticios como sucedía en la antigua Roma. Históricamente ha sido necesario establecer un orden de llamamientos cuando el causante ha fallecido sin manifestar su voluntad sucesoria; ese orden de llamamientos ha sufrido una gran evolución, casi pendular, desde cómo se solventaba en la antigüedad hasta la actualidad más próxima. Por ello, parafraseando a Carcaba Fernández ${ }^{7}$, se puede afirmar que en la sucesión intestada la posición del cónyuge viudo ha ido mejorando paulatinamente. Veámoslo.

Los criterios seguidos para efectuar los llamamientos han variado mucho a lo largo de la historia. En el viejo ius civile romano recogido en las XII Tablas se establecen tres grandes categorías de herederos cuya relación está fundamentada en la sumisión a un mismo jefe, es una relación civil ${ }^{8}$. Lo destacable es que no se hace un llamamiento genérico sino estableciendo estrictos criterios de preferencia. Así consta en Tabla V, 4-5.- Si intestato moritur, qui suus heres nec escit, adgnatus proximus familiam habeto. Si adgnatus nec escit, gentiles familiam habento. En primer lugar, son llamados los heredes sui, en su defecto la ley llama al agnado más próximo, y si no hubiere nadie de los anteriores se recurre a llamar al grupo gentilicio, a la gens, aun cuando resulta difícil definir a este grupo de herederos en base a los datos de que disponemos para ello. Este orden de llamamientos pronto desapareció. Y desapareció porque el concepto de familia varió, pasando a primar el criterio de la consanguinidad como lazo de unión entre las personas de un mismo grupo. Esta evolución consta en el orden sucesorio que estableció el pretor, que si bien heredem facere non potest si podía prometer la bonorum possessio. Es decir, la bonorum possessio se aproxima más al nuevo concepto de familia que se va formando, de forma que progresivamente va suplantando a la hereditas civil. El pretor fue estableciendo en su edicto que a la bonorum possessio fueran llamados por orden de preferencia unde legitimi, unde cognati $\mathrm{y}$ unde vir et uxor.

El pretor, en opinión de Arias $^{9}$, se hizo eco de la conciencia social, que inspirándose en la atracción de los vínculos de la sangre, consideró ligados al difunto a aquellas personas con lazos más firmes que los de la artificial agnación, que en determinados supuestos incluso eran reflejo de cierta injusticia social. Por consiguiente, se observa un evidente paso desde la familia agnaticia a la cognaticia, basada en vínculos de sangre. En los tiempos más antiguos la mujer fue considerada como hija de familia bajo la potestad del marido, de tal modo que muerto el marido, le sucedía como hija y heredera legítima y no como mujer. Cuando las mujeres dejaron de ser consideradas hijas de familia perdieron su derecho a heredar a los maridos. Asimismo, es importante recordar que el matrimonio no determina parentesco de sangre; los cónyuges pertenecen a familias distintas y sin embargo el pretor, por primera vez en la historia, les reconoce efectos sucesorios sencillamente derivados de la pura y simple relación matrimonial. Interesa en esta

7 Maa CÁRCABA FERnÁndez, Los derechos sucesorios del cónyuge viudo, Oviedo, Universidad de Oviedo, 1993, pp. 57 ss.

8 Vid. C. LóPEZ-RENDo RodrígueZ, «La sucesión intestada en la ley de las Doce Tablas», en MuriLlo ViLLAR (coord.), Estudios de derecho romano en memoria de Benito $M^{a}$ Reimundo Yanes, vol. 1, Burgos, Universidad de Burgos, 2000, pp. 533-568.

9 J. ARIAS RAMOS - J.A. ARIAS BONET, Derecho romano II. Obligaciones. Familia. Sucesiones, $18^{\mathrm{a}}$ ed., $7^{\mathrm{a}}$ reimpresión, Madrid, ed. Revista de Derecho Privado,1997, p. 873 
sede destacar esta circunstancia porque a partir de este momento, por encima de la consanguinidad, se antepone la relación de cariño o de afectividad que deriva de la relación conyugal. Es decir, se prescinde de cualquier lazo de sangre en el llamamiento al cónyuge supérstite primando otros criterios completamente ajenos.

Justiniano en las Novelas 118 (543 d.C.) y 127 (548 d.C.) configuró un nuevo sistema de sucesión intestada buscando superar la anacrónica dualidad ius civile - ius honorarium, y estableció cuatro grupos de parientes para suceder ab intestato: $1^{\circ} \operatorname{los}$ descendientes, $2^{\circ}$ los ascendientes, los hermanos de doble vínculo y los hijos de alguno de estos si ya ha fallecido, $3^{\circ}$ los hermanos y hermanas de vínculo sencillo y a los hijos de los que hubieren fallecido, y $4^{\circ}$ a los colaterales. Como el Emperador omitió al cónyuge viudo, los comentaristas han entendido que al no haber derogado el orden de llamamientos de la bonorum possessio, todos aquellos textos clásicos que regulaban la bonorum possessio unde vir et uxor continuaban vigentes, y a falta de todos los demás serían los llamados en caso de sucesión intestada.

A la vista de los órdenes de llamamientos establecidos por el ordenamiento jurídico romano a lo largo de su historia, puede inferirse que en absoluto se dio al cónyuge viudo un puesto de cierto privilegio o preferencia frente a otros parientes. Podría decirse que la consanguinidad prima por encima de cualquier lazo afectivo o de cariño, lo que supone soslayar cualquier preferencia frente a otros familiares. La tradición romanística supuso indudablemente un precedente de gran influencia a lo largo de toda nuestra historia jurídica en materia de sucesión intestada y, especialmente, el llamamiento a la herencia que se efectúa al cónyuge supérstite a falta de otros parientes del causante hasta llegar a la codificación del siglo XIX ${ }^{10}$. El cónyuge viudo únicamente se antepone al Estado ${ }^{11}$, lo que deja entrever que de partida es casi ignorado y cualquier ascenso que con posterioridad se produzca mejorará su condición. Decía Balbín de Unquera ${ }^{12}$ que la ley en la sucesión intestada, supliendo la voluntad del legislador familiar, que no se conoce, debe proceder según el orden de la naturaleza, debe interpretar los sentimientos naturales. Por ello, le sorprendía, tras divagar sobre los antecedentes romanos y la influencia cristiana, que la tendencia moderna, y escribía en 1889, momento de publicación de nuestro Código Civil, es la de restringir el derecho a lo que en el comercio común de la vida se considera familia, prescindiendo de la legal, cuya existencia no se conoce más que formando el árbol genealógico y viendo los grados de parentesco. Ante tales consideraciones, afirmaba, no se comprende en que se han fundado los legisladores de los modernos códigos para conceder a los cónyuges, respecto de los parientes y en caso de no existir herederos forzosos, un lugar en la escala, que no corresponde, ni a sus derechos durante el matrimonio, ni al amor que por regla general debe suponerse entre marido y mujer, ni a la verdadera acepción en que ha de tomar el derecho constituido la palabra familia.

Seguidamente, analizamos en diferentes ordenamientos jurídicos históricos e incluso en algunos proyectos de códigos civiles que nunca llegaron a tener vigor, la evolución de la prelación de los órdenes sucesorios y el puesto asignado en cada momento al cónyuge supérstite. A través de las diferentes fuentes históricas puede observarse cómo al cónyuge viudo se le reconocían derechos viudales pero prácticamente se le negaba la condición de heredero. Comenzaremos por la primera obra legislada tras la caída del Imperio Romano en Occidente, cuya fecha de

${ }^{10}$ Vid. sobre el desarrollo de esta cuestión hasta la etapa codificadora, M. PÉREZ EsCOLAR, «Sucesión intestada del cónyuge supérstite. Perspectiva histórica: del Derecho romano a la época de las Recopilaciones», en Revista Crítica de Derecho Inmobiliario, 2004, año $\mathrm{n}^{\circ} 80, \mathrm{~N}^{\circ} 686$, pp. 2711 ss.

11 Vid. A. Murillo Villar, «El llamamiento sucesorio a favor del estado en ausencia de herederos: de Roma a la actualidad», en Direito Romano. Poder e Direito, ediçao especial Faculdade de Direito da Universidade de Lisboa, (Coimbra Editora), Lisboa, 2013, pp. 53-70.

12 A. BALBÍn DE UnQUERA, «¿Qué lugar deben ocupar los cónyuges en la sucesión intestada?», en Revista General de Legislación y Jurisprudencia, vol. 37, nº 74, 1889, pp. 745-753 
La influencia del Derecho de Familia en la posición del cónyuge supérstite en el orden de llamamientos en la sucesión ab intestato: evolución histórica

publicación parece coincidir con la tradicional fecha de caída del Imperio Romano, el año 476 d.C.; por esta razón, el Código de Eurico es fundamentalmente, en palabras de la doctrina, una fuente de derecho romano vulgar ${ }^{13}$. Se dice en C.E. 334 que "El marido y la mujer se heredarán uno al otro tan sólo cuando no se encuentra ningún otro próximo o pariente cualquiera hasta el séptimo grado". Obviamente, por meros criterios temporales, lo recogido en este Código no es influencia del derecho justinianeo ${ }^{14}$, sino que al mantenerse el llamamiento unde vir et uxor, a falta de otros herederos preferentes, está recogiendo la influencia del sistema pretorio romano de la bonorum possessio unde vir et uxor. Habrá de entenderse que el llamamiento a los parientes colaterales es hasta el septimus gradus, que seguro, no por casualidad, coincide con lo previsto en el llamamiento unde cognati de la bonorum possessio. Por tanto, es indubitable, como dice $\mathrm{D}^{\prime} O{ }^{15}{ }^{15}$, el origen romano de esta limitación hasta el séptimo grado.

En lo sustancial, también se recoge la influencia romana en el Fuero Juzgo 4,2,11 "Del eredamiento del marido é de la muier". El marido debe aver la buena (herencia) de la muier, é la muier debe aver la buena (herencia) del marido quando non ay otro pariente fasta séptimo grado". Se infiere, pues, al igual que en el Código de Eurico, que se llamará con anterioridad a los descendientes, a los ascendientes y a los colaterales (quando non ay otro pariente), hasta el séptimo grado. Lugar en el orden de llamamientos con escasísimas posibilidades de convertirse en heredero; de hecho, tiempo después, en el Fuero Viejo de Castilla 5,2,1 se omite cualquier alusión al cónyuge supérstite. En definitiva, el cónyuge viudo queda absolutamente relegado. Idéntica situación nos encontramos en el Fuero Real 3,6,1, casi coetáneo de las Partidas, en el que se ignora por completo cualquier referencia al cónyuge supérstite, ratificado con lo previsto en el mismo Fuero Real 3,5,3, donde se determina que los bienes de quien muriera sin parientes y sin mandas pasaran al Rey.

Sin embargo, en Partidas 6,13,6 se hizo un llamamiento al cónyuge supérstite in extremis, en ausencia de otros parientes y antes que a la Cámara del Rey (Estado): "E sobre todo esto decimos que si alguno muriese sin testamento, que no hubiese parientes de los que suben o descienden por la línea derecha, si no hubiese hermano, ni sobrino, hijo de su hermano; que de éstos adelante, el pariente que fuere hallado que es más cercano del difunto hasta en el dezeno grado, ése heredará todos sus bienes. E si tal pariente no fuese hallado, e el muerto había mujer legítima cuando finó, heredará ella todos sus bienes de su marido. Eso mismo decimos del marido que heredará los bienes de la mujer en tal caso como éste. E, si por ventura, el que así muriese sin parientes, no fuese casado, entonces heredará todos sus bienes la cámara del rey". La influencia romana es evidente; el criterio que subyace en la base de los llamamientos es la presunción del afecto del causante, aunque llama la atención que al cónyuge sobreviviente se le llame en décimo lugar, lo que confronta con el principio de equidad y de afecto hacia el cónyuge. Esta situación ha llevado a que Sánchez Román ${ }^{16}$ lo califique de "verdadero oprobio", pues en ninguna legislación española se situó al cónyuge supérstite tan alejado de cualquier posibilidad de recibir la herencia del causante, ni tan siquiera en el derecho romano que le sirve de antecedente. En definitiva, las Partidas supusieron, dice Pérez Escolar, un retroceso en la historia de la sucesión intestada del cónyuge, aunque hay que considerarlo también en el marco general de su legislación. De todos modos, dice la Autora, desde un punto de vista práctico, el cónyuge no experimentaría realmente cambios en el llamamiento, pues el que había sido tradicional límite del séptimo grado desde el derecho romano era casi igual de irrealizable. El paso del séptimo al

\footnotetext{
13 A. D’Ors, El Código de Eurico. Edición. Palingenesia. Índices, Madrid, Boletín Oficial del Estado, 2014 , pp. 2 ss.

${ }^{14}$ Como sí parece mantener PÉREZ EsCOLAR, «Sucesión intestada del cónyuge supérstite», cit., pp. 2749-2750.

15 D’Ors, El Código de Eurico. Edición. Palingenesia. Índices, cit., pp. 266 ss.

${ }^{16}$ F. SÁnCHEZ Román, Estudios de Derecho civil, tomo VI, vol. 3, Madrid, SUCESORES DE RIVADENEYRA, 1910, p. 1625 .
} 
décimo no supuso un empeoramiento a la hora de hacerse efectivo, lo único que cambia es que ahora es aún más imposible ${ }^{17}$.

En las Leyes de Toro VI, VII y VIII de 1505, en las cuales se recoge la regulación relativa a la sucesión $a b$ intestato, no se encuentra ninguna referencia expresa al lugar que debe ocupar el cónyuge supérstite en el orden de prelación de llamamientos. Y ello porque no se hace alusión ni se precisa el grado de parentesco límite que debe alcanzar el llamamiento a los colaterales. Habrá de entenderse que será el décimo grado, pues así se disponía en Partidas, dado que éstas eran normas supletorias como consta en el Ordenamiento de Alcalá de 1348. Opinión de Llamas y Molina ${ }^{18}$ cuando en el comentario 42 de la Ley VIII de Toro indica que "No habiendo parientes colaterales legítimos dentro del décimo grado, la mujer y el marido se heredarán mutuamente, y en defecto de ellos entra á suceder la Cámara del Rey, según la citada ley $\sigma^{a}$ ". E igual opinión mantiene Antonio Gómez ${ }^{19}$, pues en su comentario 11 a la Ley VIII de Toro también indica que "En defecto de descendientes, ascendientes y colaterales dentro del grado profinido, se succeden reciprocamente el marido y la muger".

En la legislación posterior continuó la omisión al llamamiento del cónyuge viudo a falta de otros herederos consanguíneos, quizás por tradición del Fuero Real 3,5,13, recogido posteriormente en la Nueva Recopilación 5,8,12 y en la Novísima Recopilación 10,22,1 "Aplicacion á la Real Cámara de los bienes del difunto intestado sin herederos legítimos" "Todo hombre ó mujer que finare, y no hiciere testamento en que establezca heredero, y no hubiere heredero de los que suben ó descienden de línea derecha, ó de travieso, todos los bienes sean para nuestra Cámara". Resulta sorprendente que en nuestro derecho histórico se omita de forma reiterada el llamamiento al cónyuge sobreviviente en los casos de sucesión ab intestato ${ }^{20}$. La explicación más razonable quizás sea que la influencia del derecho romano fue tal, que se asumió como principio de autoridad las disposiciones de la Nov. 118 de Justiniano en la que se obvia absolutamente unde vir et uxor. La cuestión es si lo establecido en el Fuero Juzgo y en Partidas, respecto del llamamiento al cónyuge viudo, fue derogado por la ley de Enrique III en Nov. Rec. 10,22,1, pues no menciona ni al marido ni a la mujer. Los autores han discrepado sobre si fue derogado o no, especialmente por la vaguedad de la ley enriqueña que habla de meros parientes sin limitación de grados ni expresión de calidades. Todo indica que los llamamientos al viudo continuaron vigentes, de ahí que Escriche ${ }^{21}$ diga que "parece también favorable á esta última opinión la real cedula de 9 de octubre de 1766 (nota $1^{\text {a }}$ del tit. 22, lib. 10, Nov. Rec.) que hablando de los bienes mostrencos dispone que los bienes de los que mueren sin testamento y no dejan herederos conocidos, se adjudiquen á la real cámara con arreglo á la citada ley de Enrique III y á la dicha ley 6, tit. 13, Part. 6". También es cierto, continúa Escriche, que puede sostenerse lo contrario cuando un tiempo después "por real decreto de 31 de diciembre de 1829 é instrucción de 7 de marzo de 1831 acerca del impuesto gradual sobre las sucesiones, se estableció absolutamente que no habiendo parientes colaterales hasta el cuarto grado civil la real hacienda fuese la heredera". Parece, pues, que el llamamiento a los parientes colaterales se limitó al cuarto grado, aunque sea difícil saber los motivos, pues conforme a lo regulado en Novísima Recopilación 10,22,6

\footnotetext{
17 PÉREZ ESCOLAR, «Sucesión intestada del cónyuge supérstite», cit., pp. 2770.

${ }^{18}$ S. De Llamas y Molina, Comentario crítico-jurídico-literal a las ochenta y tres Leyes de Toro, $2^{\mathrm{a}}$ ed., Madrid, Compañía de Impresores y Libreros del Reino, 1852, p. 67.

19 A. GómeZ, Compendio de los comentarios extendidos a las ochenta y tres leyes de Toro, Madrid, 1785, reimpresión facsimilar, Valladolid, Lex Nova, 1981, p. 52.

${ }^{20}$ Vid. M. PÉREZ EsCOLAR, El cónyuge supérstite en la sucesión intestada, Madrid, Dykinson, 2003, pp. 19 ss.

21 J. ESCRICHE, Diccionario razonado de legislación y jurisprudencia, s.v. "heredero legítimo o ab intestato", $3^{\mathrm{a}}$ ed. corregida y aumentada, Madrid, Librería de la Señora Viuda e Hijos de D. Antonio Calleja, 1847, tomo $2^{\circ}$, p. 25.
} 
La influencia del Derecho de Familia en la posición del cónyuge supérstite en el orden de llamamientos en la sucesión ab intestato: evolución histórica

y 2,11,1 la disposición de Partidas cayó en desuso y a falta de herederos hasta el cuarto grado el llamado era el cónyuge supérstite ${ }^{22}$.

Paulatinamente, hasta llegar al Código civil de 1889, hubo varios proyectos legislativos previos, que seguidamente analizamos, en los que se planteó la mejoría de la posición del cónyuge supérstite, al menos en algún momento, "escalando puestos" en el orden sucesorio, si bien no terminó de establecerse como orden preferencial frente a algunos colaterales. En la "ley de mostrencos" de 1835, de 16 de mayo, "sobre las adquisiciones á nombre del Estado", se estableció un nuevo orden sucesorio. En el art. 2 se dispuso que "Corresponden al Estado los bienes de los que mиeran ó hayan muerto intestados, sin dejar personas capaces de sucederles con arreglo á las leyes vigentes. A falta de dichas personas sucederán con preferencia al Estado. Primero: Los hijos naturales legalmente reconocidos, y sus descendientes por lo respectivo á la sucesión del padre, y sin perjuicio del derecho preferente que tienen los mismos para suceder á la madre. Segundo: El cónyuge no separado por demanda de divorcio contestada al tiempo del fallecimiento, entendiéndose que á su muerte deberán volver los bienes raíces de abolengo á los colaterales. Tercero: Los colaterales desde el quinto hasta el décimo grado inclusive, computados civilmente al tiempo de abrirse la sucesión". En opinión de Pérez Escolar, "la posición que alcanzó el cónyuge supérstite con esta reforma supuso realmente un paso adelante, superador en gran medida de la tradición romanística, pues nunca antes en el curso de la historia había sido llamado con preferencia a buena parte de los parientes colaterales, y sólo pospuesto a los de grado cuarto"... "A partir de ahora puede ya empezar a hablarse de un verdadero derecho de sucesión $a b$ intestato del cónyuge sobreviviente" ${ }^{23}$. Aun siendo cierto lo anterior, no debe desconocerse que la ley indica que los bienes raíces de abolengo que hereda el cónyuge viudo deberán volver tras su muerte a los colaterales del causante, de lo cual se infiere que en rigor no es heredero propiamente dicho sino más bien usufructuario de los mencionados bienes de abolengo. Por el contario, todos aquellos otros bienes raíces que no sean de abolengo sí que los hereda el cónyuge supérstite con la misma plenitud de dominio que lo hace de los bienes muebles.

Fue al año siguiente, en el Proyecto de Código civil de 1836, cuando en el art. 2211, $5^{\mathbf{0} 24}$ el cónyuge supérstite ocupó podríamos decir que un lugar preferente, pues se proponía llamarle en ausencia de descendientes y ascendientes legítimos o legitimados, y en concurrencia y por partes iguales con los hermanos legítimos de padre y madre. La Comisión que elaboró el Proyecto de 1836 manifestó en la Exposición de Motivos que lo importante era hacer valer la voluntad presunta del causante, entendiendo que la escala de los valores afectivos de una persona normal se inclina siempre por las personas más próximas, y más próximo que el cónyuge es difícil encontrar a nadie, si me apuran en ocasiones ni los descendientes. Obviamente, fue un Proyecto que no salió adelante pero en el que se refleja la mejoría sustancial del criterio de llamamientos para el cónyuge supérstite respecto a lo recogido en la ley de mostrencos ${ }^{25}$. Lo cierto, según el Preámbulo del Proyecto, es que "Sólo se han puesto en concurrencia el cónyuge y el hermano del difunto para suceder por iguales partes, porque la Comisión, dudando entre el cónyuge y el hermano a cuál de los dos daría la preferencia, y siendo tan poderosas las razones del uno como del otro, creyó conveniente igualarlos" 26.

\footnotetext{
22 Vid. PÉREZ ESCOLAR, «Sucesión intestada del cónyuge supérstite», cit., pp. 2776.

${ }^{23}$ PÉREZ ESCOLAR, El cónyuge supérstite en la sucesión intestada, cit., p. 25.

${ }^{24}$ Proyecto Código civil de 1836, artículo 2211, $5^{\circ}$ “El cónyuge simultáneamente y por partes iguales, con los hermanos legítimos de padre y madre: los legitimados por Real gracia, se sucederán recíprocamente, y lo mismo se entenderá respecto de los que hubieren sido reconocidos o declarados por su padre".

${ }^{25}$ Vid. PÉREZ ESCOLAR, El cónyuge supérstite en la sucesión intestada, cit., p. 27 ss.

${ }^{26}$ J.F. LASso GaITE, Crónica de la codificación española. Codificación civil (Génesis e historia del Código), II, Madrid, Ministerio de Justicia, 1970, p. 127.
} 
Asimismo, en el mencionado Preámbulo del Proyecto de Código civil de 1836 se destaca que "la graduación de los afectos es la base principal del derecho de las sucesiones"27, opinión que comparto y que he tenido ocasión de poner de manifiesto en diferentes estudios ${ }^{28}$. "La ley debe ponerse en lugar del testador para distribuir los bienes de éste según es verosímil que lo hiciera él mismo si pudiese, siguiendo cierto orden de predilección, que si individualmente puede variar según el carácter de cada uno y sus circunstancias particulares, no así cuando la ley lo hace por regla general que abraza igualmente a todos los individuos del Estado"29.

Habrá que esperar hasta el Proyecto de Código de 1851 de García Goyena, en donde el cónyuge viudo no aparece en la lista de llamamientos en caso de sucesión ab intestato, sino que directamente se le adjudica una porción variable en atención a la existencia de descendientes o ascendientes del causante. Cierto que al viudo se le concibe como sucesor ab intestato en todo caso, lo cual ya era un importante avance respecto de lo previsto con anterioridad, pero en ningún caso fue el antecedente de lo que años después se contemplará en el Código Civil de 1889. Así, en el art. 773 del mencionado Proyecto de 1851se establecen los derechos hereditarios del viudo o viuda en los bienes del cónyuge premuerto: "El viudo ó viuda que, al morir su consorte, no se hallase divorciado, ó se hallase por culpa del mismo consorte, le heredará en el quinto, si deja algún descendiente; en el cuarto, si deja algún ascendiente, y á falta de unos y otros en el tercio". La razón por la cual no se incluyó al cónyuge supérstite en el orden de llamamientos a la herencia lo expone muy gráficamente García Goyena ${ }^{30}$, pues nos informa que una vez revocada la base de la Comisión General que atribuía al viudo o viuda el concepto y derechos de herederos forzosos aun concurriendo con hijos y descendientes, por ser irregular, monstruosa y chocante con todos los principios que rigen en materia de herencias sin testamento, y por haberla hallado impracticable, se pensó en mejorar la suerte de los viudos.

Y esta "suerte de los viudos", obviamente, la basaron en una razón de afecto presunto. Por ello, si hubiera habido testamento y el causante omitió al viudo, nada se puede hacer porque está la voluntad manifestada de manera explícita. Ahora bien, dice García Goyena, si el causante murió intestado el legislador presume que ambos cónyuges vivieron y se amaron como buenos esposos; y seguro que el difunto hubiera asegurado el bienestar del sobreviviente si hubiera hecho testamento. En definitiva, con la disposición contemplada en el art. 773 se está siguiendo la regla general de respeto de la voluntad presunta del difunto. Es decir, el legislador deduce dicha voluntad presunta del amor o cariño. Esta presunción es política por cuanto realza el honor y la santidad del matrimonio; es también humana porque evita que el viudo o viuda pase de manera inmediata del bienestar a la mendicidad y también es racional porque es difícil creer que el difunto quisiera que sus bienes pasaran a otras manos, y que el cónyuge supérstite partícipe de sus goces y comodidades quedara sumido en la indigencia ${ }^{31}$.

En el vigente Código Civil español, art. 913, redacción actual según la Ley 11/1981, de 13 de mayo, de modificación del Código Civil en materia de filiación, patria potestad y régimen económico del matrimonio, se establece que "A falta de herederos testamentarios, la ley defiere la herencia a los parientes del difunto, al viudo o viuda y al Estado". Obviamente, dada la ubi-

\footnotetext{
${ }^{27}$ LASso GaITE, Crónica de la codificación española. Codificación civil II, cit., p. 129.

28 Vid. A. MuriLlo VILlaR, «Aproximación al origen del fideicomiso de "eo quod supererit», en Bullettino dell'Istituto di Diritto Romano "Vittorio Scialoja", vol. XCII - XCIII, Milano, 1989, pp. 142 ss., y en «Anotaciones sobre el proceso de recepción de las causas de revocación de la donatio mortis causa romana», en Estudios en Homenaje al Prof. Armando Torrent, Madrid, Dykinson, 2016, pp. 583 ss.

${ }^{29}$ Lasso GaITE, Crónica de la codificación española. Codificación civil II, cit., p.126.

${ }^{30}$ F. García Goyena, Concordancias, motivos y comentarios del Código civil español I, Madrid, 1852, reimpresión, Zaragoza, Cometa S.A., 1974, pp. 405 ss.

${ }^{31}$ García GoYena, Concordancias, motivos y comentarios del Código civil español I, cit., p. 502.
} 
La influencia del Derecho de Familia en la posición del cónyuge supérstite en el orden de llamamientos en la sucesión ab intestato: evolución histórica

cación del precepto entre las "Disposiciones generales" de la Sucesión Intestada, es una redacción genérica, sin precisión, pues es menester saber qué se entiende por parientes del difunto, y especialmente hasta que grado de parentesco alcanza el llamamiento. Para ello es preciso acudir a lo regulado en los artículos 930 y siguientes. Así, en primer lugar son llamados en línea recta descendente los hijos y sus descendientes. A falta de los anteriores se llama a los ascendientes. Si sucediere que no existen personas en los llamamientos precedentes, dice el art. 943 "heredarán el cónyuge y los parientes colaterales por el orden que se establece en los artículos siguientes". Esta regla se precisa en el art. 944 en el que se antepone el cónyuge supérstite a todos los demás parientes colaterales. Establece el mencionado art. 944 "En defecto de ascendientes y descendientes, y antes que los colaterales, sucederá en todos los bienes del difunto el cónyuge sobreviviente". Por consiguiente, el cónyuge viudo es preferido a la herencia del difunto con prioridad a cualquier hermano del causante. "Esta favorable evolución es lógica pues nadie tiene título más legítimo que el viudo para recibir los bienes hereditarios, ya sea la norma para fijar los derechos sucesorios el cariño, el reconocimiento de los beneficios recibidos, o la intimidad del vínculo, porque hay que reconocer que el matrimonio ordinariamente establece entre los contrayentes un nexo más fuerte que el de la sangre, y que en la sociedad moderna prima la familia nuclear frente a la troncal". Así consta en la Exposición de Motivos del Proyecto de Ley de Modificación del Código civil en materia de filiación, patria potestad y régimen económico del matrimonio (BOCG/CD, 14 septiembre de 1979). Estas ideas no constan en el texto definitivo de la Ley 11/1981 de 13 de mayo, a pesar de lo cual la definición de la línea de pensamiento es la misma ${ }^{32}$. Por lo que respecta a los derechos del cónyuge viudo, recogidos básicamente en los vigentes arts. 834 y ss. del C.C. español, relativo al usufructo de parte de los bienes hereditarios, en opinión de Cámara Puente, España aún destaca en el contexto comparado por la debilidad de la protección del cónyuge ${ }^{33}$.

Es evidente, pues, que con la modificación de la Ley 11/1981, de 13 de mayo, la situación del cónyuge viudo ha mejorado, se ha producido un tránsito de la familia parental o troncal, a otra más reducida o conyugal derivada de la importancia adquirida paulatinamente por la relación matrimonial frente a la parentela de sangre ${ }^{34}$; sin embargo, a día de hoy, han transcurrido más de treinta y seis años y ha habido importantísimas transformaciones en muchísimos ámbitos; el nuevo régimen democrático implantado en España a partir de la Constitución de 1978, ha favorecido los cambios sociales, culturales, económicos, morales, éticos, de concepción familiar, etc., es decir, se ha producido un cambio drástico de mentalidad social. Y todos sabemos que el derecho como producto histórico es un fiel reflejo de la sociedad de cada momento ${ }^{35}$, de la realidad social a la que sirve $\mathrm{e}^{36}$, por ello es razonable que en tema de sucesiones los cambios se reclamen insistentemente ${ }^{37}$. Parafraseando a Jiménez Liébana, puede afirmarse que hay necesidad no sólo de mejorar la situación del cónyuge viudo en la sucesión intestada, sino de reformar globalmente

32 Vid. M MáRCABA FERNÁNDEZ, «Derechos del cónyuge viudo en la sucesión intestada tras la reforma del Código Civil operada por Ley 11/1981 de 13 de mayo», en La Ley: Revista jurídica española de doctrina, jurisprudencia y bibliografía, $n^{o}$ 1, 1986, p. 1177 nts.1 y 2. E. DE LA IGLESIA PRADOS, Análisis de la sucesión intestada, Valencia, Tirant lo Blanch, 2012, pp. 212 ss. nt.1.

${ }^{33}$ CÁmARA LAPUENTE, «¿Derecho europeo de sucesiones? Un apunte», cit., p. 1201.

34 Vid. PÉREZ ESCOLAR, El cónyuge supérstite en la sucesión intestada, cit., pp. 114 ss.

${ }^{35}$ En la Ley 11/1981 se recogió la realidad económica de comienzos de los años ochenta y se reflejó el sentir general en pro de la necesidad de un cambio en muchos de los ámbitos del derecho de familia, cambio que, a pesar de haber suscitado algunas críticas por considerarla en cierta medida excesiva, fue bien acogido tanto por la doctrina como por la sociedad española, como manifiesta $\mathrm{M}^{\mathrm{a}}$ NúÑEZ NúÑEZ, La sucesión intestada de los parientes colaterales, Madrid, Dykinson, 2007, pp. 125 ss.

36 Vid. A. Murillo Villar, «De la importancia de recordar que el derecho es un producto histórico», en Foro Social $n^{o}$ 4, Revista de la Escuela de Relaciones Laborales de Burgos, Burgos, 2003, pp. 8-12.

37 Vid. D. JIMÉNEZ LIÉBANA, «La mejora de la posición del cónyuge viudo en la sucesión intestada del Código Civil», en Herrero Oviedo (coord.), Domínguez Luelmo y García Rubio (dir.), Estudios de derecho de sucesiones: "Liber amicorum" T. F. Torres García, Madrid, LA LEY, 2014, pp. 707 ss. 
el derecho de sucesiones, implicando éstas la anteposición del cónyuge a los ascendientes, así como la de llamar al cónyuge viudo en primer lugar junto con los descendientes en la porción de un tercio ${ }^{38}$.

Con anterioridad a la Ley 11/1981, que como puede observarse en su título omite toda referencia al derecho sucesorio aunque sí refiere cuestiones puntuales del derecho de familia, de ahí nuestra reiterada opinión de cómo cualquier cambio en materia de familia influye en el derecho sucesorio, se establecía en el art. 913 que "A falta de herederos testamentarios, la Ley defiere la herencia,... a los parientes legítimos y naturales del difunto, al viudo o viuda, y al Estado". La mencionada reforma de 1981 suprimió los arts. 952 y 953 del vigente Código Civil, relativos al orden sucesorio que ocupaba el cónyuge supérstite junto con los sucesores colaterales, y que a todos los efectos sucedía a falta de hermanos y sobrinos siempre y cuando no estuviera separado por sentencia firme de separación personal. Es decir, que en la regulación anterior a 1981 y por reiterada Jurisprudencia ${ }^{39}$, los arts. 952 y 953 daban preferencia al cónyuge viudo que no estuviera separado legalmente sobre los parientes colaterales que no fueran hermanos o hijos de estos a la hora de suceder al difunto ${ }^{40}$. En definitiva, podemos decir que con la reforma el cónyuge supérstite "escaló" posiciones de mejora en el orden sucesorio y se antepuso a los hermanos del difunto y a los demás colaterales en defecto de ascendientes y descendientes. Es decir, la concepción familiar progresó a favor del matrimonio y en demérito de la parentela, dando preferencia al afecto conyugal. Conviene recordar que desde la Ley 13/2005, de 1 de julio, por la que se modifica el Código Civil en materia de derecho a contraer matrimonio, en el art. 44,2 del mencionado C.C. rige que "El matrimonio tendrá los mismos requisitos y efectos cuando ambos contrayentes sean del mismo o de diferente sexo". Por consiguiente, regulado el matrimonio entre personas del mismo sexo, el término cónyuge alcanza por igual a las personas con independencia de su género. Y todo ello, como se indica en el preámbulo de la citada Ley 13/2005, porque es preciso en cada momento histórico atender a sus valores dominantes, de ahí que la relación y convivencia de pareja, basada en el afecto, sea expresión genuina de la naturaleza humana y constituya un cauce destacado para el desarrollo de la personalidad. Destacamos este apunte porque una vez más se colige que el derecho de familia afecta al derecho de sucesiones, y en este ámbito el afecto o cariño adquiere un carácter esencial. Recordar que en el derecho común español, a diferencia de la normativa autonómica, no están reguladas aún las uniones de hecho, por ello en el ámbito hereditario, sin duda uno de los más controvertidos en el ámbito de las parejas estables no casadas, es donde se da en la práctica una mayor distancia frente al tratamiento de las uniones matrimoniales. Es decir, que "el Código Civil sólo reconoce derechos sucesorios al cónyuge del causante. Sin embargo, la realidad social de las uniones extramatrimoniales ha llevado a plantearse si, cuando reúnen ciertos requisitos como son constitución voluntaria, estabilidad y permanencia en el tiempo con apariencia pública de comunidad de vida similar a la matrimonial, los miembros de este tipo de uniones deben ser equiparados en derechos a los cónyuges" ${ }^{41}$.

Finalmente, y al objeto de destacar la que a día de hoy tal vez sea la posición más privilegiada en el orden de prelación en la sucesión intestada, abordamos la cuestión en el derecho catalán $^{42}$. En el actual derecho civil de Cataluña se antepone el llamamiento del cónyuge viudo

38 JiMÉNEZ LIÉBANA, «La mejora de la posición del cónyuge viudo en la sucesión intestada del Código Civil», cit., p. 715.

${ }^{39}$ F. BONET RAMÓn, Código civil comentado con su apéndices forales, Madrid, AGUILAR. 1964, p. 719.

40 Vid. PÉREZ ESCOLAR, El cónyuge supérstite en la sucesión intestada, cit., pp. $48 \mathrm{ss}$.

${ }^{41}$ E. PÉREZ-PUJAZÓN - F.J. RODRÍGUEZ RAMOS, «El régimen de sucesión intestada en España. Régimen general», en Economist \& Jurist, Difusión Jurídica y Temas de Actualidad, S.L., (21), nº 168, 2013, p. 21.

${ }^{42}$ Por cierto, en la Ley 40/1960, de 21 de julio, sobre Compilación del Derecho Civil Especial de Cataluña, Título IV, De la sucesión intestada, arts. 248 - 251, regía lo dispuesto en el Código civil español; como excepción se establecía en el art. 250 que "El viudo o la viuda a quien su difunto consorte no le hubiese otorgado disposición alguna por 
La influencia del Derecho de Familia en la posición del cónyuge supérstite en el orden de llamamientos en la sucesión ab intestato: evolución histórica

a los ascendientes, es decir, se antepone la afectividad del matrimonio o pareja conviviente a los padres o progenitores. Así, en el art. 442-3.2 "Si el causante muere sin hijos ni otros descendientes, la herencia se defiere al cónyuge viudo o al conviviente en pareja estable superviviente. En este caso, los padres del causante conservan el derecho a legítima" ${ }^{43}$. La regulación vigente de la sucesión intestada se recoge en el libro IV del Código Civil catalán, en virtud de la Ley 10/ 2008, de 10 de julio, del libro cuarto del Código Civil de Cataluña, relativo a las sucesiones, que vino a derogar Ley 40/1991, de 30 de diciembre, Código de Sucesiones por Causa de Muerte en el Derecho Civil de Cataluña (Vigente hasta el 01 de Enero de 2009), que en su art. 333 establecía sustancialmente lo mismo: "De fallecer el causante sin hijos ni descendientes, le sucederá el cónyuge sobreviviente". Es decir, el cónyuge viudo era llamado en segundo lugar ${ }^{44}$, se antepone a los padres, a diferencia de lo establecido en el derecho civil común. En paralelo al CSCat., la LUEP (ley 10/1998, de 15 de julio, de uniones estables de pareja) en su art. 34 recogía los derechos sucesorios ab intestato del miembro superviviente de una pareja homosexual, el cual tenía derecho a una cuarta parte del valor de la herencia si concurría con descendientes o ascendientes, o a la mitad si es con otros colaterales, o a toda la herencia si no hay descendientes, ni ascendientes ni colaterales hasta el tercer y cuarto grado. En este caso, el orden sucesorio intestado, cuando el causante convive maritalmente con una persona de su mismo sexo, se altera, pasando a ocupar el cuarto lugar o el tercero si es llamado con colaterales hasta el segundo grado por consanguinidad o adopción (hermanos) o si han premuerto, los hijos de estos (sobrinos) ${ }^{45}$. Sin embargo, en el CCCat. en vigor, esta posición ha cambiado y la novedad reside en incorporar y equiparar a la pareja de hecho en las mismas condiciones que al cónyuge supérstite. Se equiparan completamente los derechos del cónyuge viudo con los atribuidos a una pareja estable, sin distinguir en esta última si se trata de una pareja heterosexual u homosexual ${ }^{46}$.

A los efectos de este trabajo nos interesa destacar, aun tratándose de legislación derogada por la ley 25/2010, de 29 de julio, del libro segundo del Código Civil de Cataluña, relativo a la persona y la familia, que las disposiciones que regulaban el nuevo orden sucesorio derivado del Código de Sucesiones de 1991 y las interferencias ocasionadas por la ley 10/1998, de 15 de julio, de uniones estables de pareja (LUEP), llevan a la conclusión de que el orden sucesorio intestado regular fue meridianamente modificado. Cuáles fueron los motivos? Difícil conocerlos, pero lo cierto es que dichas modificaciones no tuvieron su origen en vínculos de parentesco ni de matrimonio, sino en la convivencia estable contractualmente o de la relación de pareja establecida contractualmente o de la relación de pareja estable homosexual establecida de acuerdo con la ley ${ }^{47}$. Presumiblemente, el legislador tuvo muy en cuenta el momento histórico que se vivía, así como la afectividad y el cariño entre las personas que conviven con independencia del género de cada cual, sin olvidar el creciente nivel de aceptación que se tiene en el seno de nuestra sociedad. En definitiva, como bien aventuraba Llebaría Samper, "tanto el fundamento de la sucesión intestada como el respecto al art. $33 \mathrm{CE}$ recomiendan que el legislador no se distancie en el orden de llamamientos de lo que hubiera expresado hipotéticamente la voluntad del causante medio, y

causa de muerte en codicilo o en capitulación matrimonial, adquirirá por ministerio de la Ley libre de fianza en la sucesión ab intestato de éste el usufructo de la mitad de la herencia, si los herederos ab intestato son descendientes o ascendientes le gítimos del difunto, y el usufructo sobre la totalidad en los demás casos".

${ }^{43} \mathrm{M}^{\mathrm{a}}$ YSÀs SOLANES, «La sucesión intestada en Cataluña», en GETE-AlONSO Y CALERA, (dir.), Tratado de derecho de sucesiones. Código civil y normativa civil autonómica: Aragón, Baleares, Cataluña, Galicia, Navarra, País Vasco, vol. 2, Pamplona, Thomson Reuters, 2011, pp. 1681 ss.

${ }^{44}$ Vid. M M YSÀs SOLANES, «La sucesión intestada en Cataluña: (Estado de la cuestión)», Libro-Homenaje al profesor Manuel Amorós Guardiola, vol. 2, Madrid, CENTRO DE ESTUDIOS, 2006, pp. $2051 \mathrm{ss}$.

45 S. NAVAs NAVARRo, «La sucesión intestada de la Generalidad de Cataluña», Anuario de Derecho Civil, vol. 55, $n^{\circ} 3$, 2002, pp. 1058 ss.

46 Vid. A. Hernández Moreno - F.M. ECHEVERría SuMmers, «El régimen de la sucesión intestada en Cataluña», en Economist \& Jurist, Difusión Jurídica y Temas de Actualidad, S.L., (21), no. 168, 2013, pp. 38 ss.

47 YSÀs SOLANES, «La sucesión intestada en Cataluña: (Estado de la cuestión)», cit., p. 2093. 
esto tiene que ver mucho con los afectos y sentimientos subyacentes en todo proyecto de convivencia familiar" 48 .

En los demás derechos forales o autonómicos con competencia para regular sus derechos sucesorios, Aragón, Baleares, Navarra, País Vasco y Galicia, no han introducido grandes cambios en lo que afecta a nuestro objetivo: el orden de llamamientos en la sucesión intestada o legal, como se denomina en algunos de estos cuerpos legales. Comenzando por Aragón, se observa que en el Decreto Legislativo 1/2011, de 22 de marzo, del Gobierno de Aragón, por el que se aprueba, con el título de «Código del Derecho Foral de Aragón», el Texto Refundido de las Leyes civiles aragonesas, art. 517, que ha sustituido al art. 202 de la Ley 1/1999, de 24 de febrero, de Sucesiones por Causa de Muerte (Vigente hasta el 23 de abril de 2011) ${ }^{49}$, los herederos son llamados jerárquicamente ${ }^{50}$. El cónyuge supérstite es colocado en el mismo lugar que en el Código Civil español, si bien se le excluye de una parte del patrimonio hereditario, los llamados bienes recobrables o troncales ${ }^{51}$. En definitiva, son llamados jerárquicamente y por este orden: los descendientes; los ascendientes; el cónyuge; los parientes colaterales privilegiados (hermanos, hijos y nietos de hermanos); los parientes colaterales ordinarios, y finalmente, la Comunidad Autónoma de Aragón ${ }^{52}$.

Por lo que respecta a Navarra, indicar que continúa procediéndose al llamamiento del cónyuge supérstite de acuerdo a lo establecido en la Ley 1/1973, de 1 de marzo, por la que se aprueba la Compilación del Derecho Civil Foral de Navarra, también llamado Fuero Nuevo de Navarra, modificada por la Ley Foral 5/1987, de 1 de abril, en la Ley 304 en la que se establece el orden de suceder para los bienes no troncales ${ }^{53}$. La posición del cónyuge sobreviviente en este

${ }^{48}$ S. LLEBARÍA SAMPER, «La sucesión intestada del conviviente homosexual: Comentario a y desde la STSJ Cataluña, 9.3.2009», en InDret: Revista para el Análisis del Derecho, $n^{\circ}$. 3, 2009, p. 8 (www.indret.com).

${ }^{49}$ PÉREZ ESCOLAR, El cónyuge supérstite en la sucesión intestada, cit., pp. 157 ss.

${ }^{50}$ Vid. M ${ }^{\text {a }}$ C., BAYOD LÓPEZ, «La sucesión intestada en Aragón», en GETE-ALONSO Y CALERA (dir.), Tratado de derecho de sucesiones. Código civil y normativa civil autonómica: Aragón, Baleares, Cataluña, Galicia, Navarra, País Vasco, vol. 2, Pamplona, Thomson Reuters, 2011, pp. 1611 ss.

${ }^{51}$ Código del Derecho Foral de Aragón, Decreto Legislativo 1/2011, de 22 de marzo, del Gobierno de Aragón:

Artículo 517 Orden de sucesión legal

1. En la sucesión legal la herencia se defiere en primer lugar a los parientes de la línea recta descendente.

2. En defecto de descendientes:

1. ${ }^{\circ}$ Los bienes recobrables y los troncales se defieren a las personas con derecho a recobro y a los parientes troncales, respectivamente.

2. ${ }^{\circ}$ Los bienes no recobrables ni troncales, y también éstos si no hay parientes con derecho preferente, se defieren, sucesivamente, a los ascendientes, al cónyuge, a los colaterales hasta el cuarto grado y a la Comunidad Autónoma o, en su caso, al Hospital de Nuestra Señora de Gracia.

${ }^{52} \mathrm{M}^{\mathrm{a}}$ A. ARQUED SANZ, «El régimen de sucesión intestada en Aragón», en Economist \& Jurist, Difusión Jurídica y Temas de Actualidad, S.L., (21), $n^{\circ}$. 168, 2013, pp. 56-61.

${ }^{53}$ Ley $1 / 1973$, de 1 de marzo, por la que se aprueba la Compilación del Derecho Civil de Navarra

LEY 304. Orden de suceder

La sucesión legal en bienes no troncales se deferirá por el siguiente orden de llamamientos, cada uno de los cuales será en defecto de todos los anteriores y excluirá a todos los posteriores:

1) Los hijos matrimoniales, los adoptados con adopción plena y los no matrimoniales cuya filiación llegue a determinarse legalmente; por partes iguales, y con derecho de representación en favor de sus respectivos descendientes.

2) Los hermanos de doble vínculo por partes iguales, y los descendientes de los premuertos, por representación.

3) Los hermanos de vínculo sencillo por partes iguales, y los descendientes de los premuertos, por representación.

4) Los ascendientes de grado más próximo. Si fuesen de distintas líneas, la herencia se dividirá por mitad entre ambas, y dentro de cada línea, por partes iguales.

5) El cónyuge o pareja estable no excluido del usufructo de fidelidad conforme a la Ley 254.

6) Los colaterales no comprendidos en los números 2) y 3) hasta el sexto grado, sin distinción de vínculo doble o sencillo, ni de líneas, excluyendo los de grado más próximo a los de más remoto, sin representación y siempre por partes iguales.

7) En defecto de los parientes comprendidos en los números anteriores, sucederá la Comunidad Foral de Navarra, la cual, tras proceder a la liquidación de los bienes y derechos de la herencia, la destinará a fines de interés social, incrementando la dotación presupuestaria que para estos fines se prevea en los Presupuestos Generales de Navarra. 
La influencia del Derecho de Familia en la posición del cónyuge supérstite en el orden de llamamientos en la sucesión ab intestato: evolución histórica

ordenamiento resulta muy poco favorecedora en comparación con lo que son las modernas tendencias legislativas, encaminadas todas ellas a fortalecer dicha figura, pues, además, aparece en un lugar de la jerarquía sucesoria que actualmente se considera superado ${ }^{54}$, a pesar de haber sido modificado con actualizaciones que soslayaron la mejora en el orden prelativo de los llamamien$\operatorname{tos}^{55}$.

A diferencia de Aragón y Navarra, el País Vasco se ha dotado por Ley 5/2015, de 25 de junio, de un nuevo Derecho Civil Vasco, que se aplica en todo el ámbito territorial de la Comunidad Autónoma, salvo aquellos preceptos en que expresamente se declara su vigencia únicamente para un territorio concreto (art. 8). Entre las novedades que introduce la Ley están las referidas a la sucesión intestada ${ }^{56}$. La nueva Ley, que sigue distinguiendo entre la sucesión en los bienes troncales y los no troncales, modifica el orden de suceder establecido en la Ley 3/1992 de "Derecho civil foral" y en el Código Civil para el caso de fallecer sin testamento ${ }^{57}$. El texto aprobado establece que el cónyuge viudo o el superviviente de la pareja de hecho heredarán en defecto de hijos y descendientes del difunto, que heredan en primer lugar, y antes que los padres y ascendientes del mismo ${ }^{58}$. En el orden del llamamiento, el cónyuge o pareja de hecho se antepone a los ascendientes (art. 114), que, además, no son legitimarios (art. 47). Curiosamente, en la exposición de Motivos no se da razón alguna del porqué de este cambio tan radical. Y no distingue la ley entre bienes comunes o privativos, por lo que, en caso de matrimonio o constitución de pareja de hecho, habrá que tener muy en cuenta esta disposición. Así, pues, el orden

${ }^{54}$ PÉREZ EsCOLAR, El cónyuge supérstite en la sucesión intestada, cit., pp. 167 ss. Vid. también, M ${ }^{\mathrm{a}}$ L. Arcos Vieira, «La sucesión intestada en Navarra y el País Vasco», en GETE-ALONSO Y CALERA (dir.), Tratado de derecho de sucesiones. Código civil y normativa civil autonómica: Aragón, Baleares, Cataluña, Galicia, Navarra, País Vasco, vol. 2, Pamplona, Thomson Reuters, 2011, pp. 1822 ss.; J. IRIBARREN GOÑI-M. ÚRIZ AYESTARÁN, «El régimen de sucesión intestada en Navarra», en Economist \& Jurist, Difusión Jurídica y Temas de Actualidad, S.L., (21), nº. 168, 2013, pp. $62-66$.

55 .- La Ley 304 apartado 5 por el artículo 11.2 de la Ley Foral 6/2000, de 3 julio, de Igualdad Jurídica de Parejas Estables de Navarra.

.- La Ley 304 también fue modificada por Ley Foral 5/1987, de 1 abril.

.- La Ley 304 apartado 7), asimismo fue modificado por la Ley Foral 10/2016, de 1 de julio, de actualización del régimen regulador de la sucesión legal a favor de la Comunidad Foral de Navarra.

56 También es una novedad, aunque referida a la sucesión testamentaria, que el testador puede privar absolutamente de la legítima, reducida ahora a un tercio (1/3) del patrimonio, a los legitimarios: hijos y descendientes, el cónyuge viudo o pareja de hecho del causante, desapareciendo como tales legitimarios los padres y demás ascendientes, y todo ello sin tener que dar ninguna explicación. Consecuentemente, el causante puede disponer libremente de su patrimonio; es lo que se denomina "apartamiento", contemplado en el art. 51 de la citada Ley 5/2015. En la Exposición de Motivos no se aducen las razones del tenor de dicha regulación, pero no es difícil colegir que el legislador se ha hecho eco de la opinión social y ha dotado a los ciudadanos vascos de un mayor grado de libertad a la hora de testar. Cada vez son más los supuestos en los que las relaciones familiares son muy difíciles e incluso inexistentes. Pongamos por caso los padres e hijos que viven alejados, que no mantienen ningún contacto ni físico ni emocional, o que entre ellos, por diferentes causas, existe una enemistad larvada que les ha llevado a distanciarse, a veces tiene que ver con el alcoholismo, la ludopatía, la drogadicción o problemas similares, y obviamente los padres no quieren dejarles dinero para que se lo gasten en esos vicios; es decir, existen muchísimas situaciones en las que no existe ningún vínculo de afectividad entre el causante y el heredero forzoso legitimario. De nuevo, esta situación pone de manifiesto la trascendencia del afecto, del cariño, de la proximidad, por encima de la relación de consanguinidad, a la hora de nombrar herederos, ya sea por el propio causante en testamento o por la ley supliendo la voluntad del causante en los llamamientos a la herencia ab intestato.

57 Vid. M. M. KARRERA EGIALDE, «La sucesión intestada en Navarra y el País Vasco», en GETE-ALONSO Y CALERA (dir.), Tratado de derecho de sucesiones. Código civil y normativa civil autonómica: Aragón, Baleares, Cataluña, Galicia, Navarra, País Vasco, vol. 2, Pamplona, Thomson Reuters, 2011, pp. 1829 ss.; G.H. GALICIA AIZPURUA, «El régimen de sucesión intestada en el País Vasco», en Economist \& Jurist, Difusión Jurídica y Temas de Actualidad, S.L., (21), nº 168,2013 , pp. 24-31.

58 Vid. HeBRERo HeRnÁNDEZ, J.A., 2015: El nuevo Derecho Civil Vasco, https://tuguialegal.com/2015/07/20/el-nuevoderecho-civil-vasco/(última consulta realizada el 9 de febrero de 2017); GRANADOS DE ASENSIO, D. Ma., 2015: Notas sobre la Ley 5/2015, de 25 de junio, de Derecho Civil Vasco, http://www.notariosyregistradores.com/web/cuadros/ ley-de-derecho-civil-vasco/. http://www.paisvasco.notariado.org/?do=info\&option=derecho_foral (última consulta realizada el 9 de febrero de 2017). 
de suceder de acuerdo con lo previsto en el artículo 112, es el siguiente: $1^{\circ}$ Hijos o descendientes; $2^{\circ}$ Cónyuge viudo no separado legalmente o por mutuo acuerdo que conste de modo fehaciente o el superviviente de la pareja de hecho extinta por fallecimiento de uno de sus miembros; $3^{\circ}$ Ascendientes y $4^{\circ}$ Colaterales dentro del cuarto grado, por consanguinidad o adopción. Por consiguiente, buscado o no, lo cierto es que en lo que respecta al posicionamiento del cónyuge viudo en el orden de llamamientos la regulación vasca y la catalana son coincidentes. La coincidencia se plasma en la mejoría de la posición del cónyuge a la hora de acceder a la herencia intestada, ya sea frente a lo recogido en el Código Civil ya sea frente a lo establecido en otros ordenamientos de las demás Comunidades Autónomas con derecho propio ${ }^{59}$.

Finalmente, indicar que en el Decreto Legislativo 79/1990, de 6 de septiembre, por el que se aprueba el Texto Refundido de la Compilación del Derecho Civil de las Islas Baleares, en su art. 53 (para Mallorca y Menorca), se dice: "La sucesión ab intestato se regirá por lo dispuesto en el Código Civil, sin perjuicio, en su caso, de los derechos que se reconocen al cónyuge viudo en el art. 45 y de lo previsto en el art. 51, ambos de esta Compilación", y en el art. 84 (para Ibiza y Formentera) se establece "La sucesión intestada en Eivissa y Formentera se rige por las normas del Código civil. No obstante lo dispuesto en el párrafo anterior, el cónyuge viudo adquirirá, libre de fianza, en la sucesión del consorte difunto, el usufructo de la mitad de la herencia en concurrencia con descendientes y de dos terceras partes de la herencia en concurrencia con ascendientes" $"$. Y de modo similar se manifiesta la Ley de Derecho Civil de Galicia (Ley 2/ 2006, de 14 de junio), que establece en su art. 267 que "Si no existieran personas que tengan derecho a heredar de acuerdo con lo establecido en la presente ley y lo dispuesto en las secciones 1. ${ }^{a}, 2^{a}$ y 3. ${ }^{a}$ del capítulo IV del título III del Código civil, heredará la Comunidad Autónoma de Galicia"61. Esto demuestra, a juicio de Nieto Alonso ${ }^{62}$, la poca relevancia que el legislador gallego ha querido concederle a la sucesión ab intestato, desechando la posibilidad de una regulación concreta y optando por la técnica de la remisión. Es decir, que tanto en Islas Baleares como en Galicia el orden de llamamientos sigue siendo el del derecho común, si bien en ambos se ha asimilado el conviviente de hecho al cónyuge supérstite ${ }^{63}$.

${ }^{59}$ En una dirección muy similar se encamina el Anteproyecto de Ley 2009, de la Generalitat Valenciana de Sucesiones, art. 97.- "La sucesión intestada a favor del cónyuge viudo o del conviviente estable.

Si el causante muere sin hijos ni otros descendientes con derecho a sucederle ab intestato conforme al artículo anterior, esta Ley llama a la sucesión intestada de aquél a su cónyuge viudo o a la persona que con él conviviera en unión estable y le sobreviva. Si al difunto le sobrevivieren sus padres o alguno de ellos, aquéllos o éste conservarán su legítima en concurrencia con la atribución intestada al viudo o conviviente estable supérstite".

http://www.notariosyregistradores.com/PROYECTOS/proyectos\%20concretos/Valencia-sucesiones.pdf

http://docplayer.es/15597071-Anteproyecto-de-ley-2009-de-la-generalitat-valenciana-de-sucesiones.html (última consulta realizada el 9 de febrero de 2017).

${ }^{60}$ F. LlODRÀ GRIMALT, «La sucesión intestada en Baleares», en GETE-AlONSO y CALERA (dir.), Tratado de derecho de sucesiones. Código civil y normativa civil autonómica: Aragón, Baleares, Cataluña, Galicia, Navarra, País Vasco, vol. 2, Pamplona, Thomson Reuters, 2011, pp. 1713 ss.; también en «La sucesión intestada en las Illes Balears», en CuAdRAdo IGlesias y NúÑEz Boluda (dir.), Estudios jurídicos en homenaje al profesor Manuel García Amigo, vol. 2, Madrid, LA LEY, 2015, pp. 2027 ss. No obstante, "cuando el jurista se aleja de la realidad social sobre la que se proyecta el derecho, emprende un camino desviado", a propósito del problema del derecho supletorio en materia de derecho de sucesiones en las Islas Baleares, vid. G. LEÓN PIÑA, «El régimen de sucesión intestada en las Islas Baleares», en Economist \& Jurist, Difusión Jurídica y Temas de Actualidad, S.L., (21), nº. 168, 2013, pp. 48-55.

${ }^{61}$ Por lo que respecta a la sucesión del cónyuge viudo y de la pareja de hecho supérstite, A. NIETO ALONSO, «La sucesión intestada en el derecho civil de Galicia», en GETE-ALONSO y CALERA (dir.), Tratado de derecho de sucesiones. Código civil y normativa civil autonómica: Aragón, Baleares, Cataluña, Galicia, Navarra, País Vasco, vol. 2, Pamplona, Thomson Reuters, 2011, pp. 1771 ss.

${ }^{62}$ Vid. A. NiETo AlONSO, «El régimen de sucesión intestada en Galicia», en Economist \& Jurist, Difusión Jurídica y Temas de Actualidad, S.L., (21), $n^{\circ}$. 168, 2013, pp. 32-37.

${ }^{63}$ La Ley 18/2001, de 19 de diciembre, de parejas estables de las Islas Baleares, dice en su art. 13.- "Tanto en los supuestos de sucesión testada, como en los de intestada, el conviviente que sobreviviera al miembro de la pareja 
La influencia del Derecho de Familia en la posición del cónyuge supérstite en el orden de llamamientos en la sucesión ab intestato: evolución histórica

\section{CONCLUSIÓN}

A modo de epílogo puede afirmarse que, bien por razón de consanguinidad, como en la antigua Roma, bien por razón de matrimonio, como en el derecho histórico, en el Código Civil o en las leyes forales hasta finales del siglo XX, bien por razón de afectividad, cariño o convivencia sin distinción de género, como dispone la más reciente legislación, tanto el cónyuge supérstite como la pareja conviviente han ido mejorando su posición en el orden de prelación de llamamientos en la sucesión intestada. Esta mejoría ha coincidido en el tiempo con una meridiana evolución en el concepto de familia, de troncal a nuclear, que está siendo relegada en favor de las relaciones de convivencia estables sean o no matrimoniales. Además, la citada mejoría ha evolucionado a la par que las transformaciones sociales, económicas, culturales y morales. Y todo ello ha confluido en que el cónyuge viudo o conviviente estable ocupen un lugar preferente en los llamamientos frente a cualquier otro pariente consanguíneo, salvo que sean descendientes directos en primer grado, cuando los hubiere, de modo tal que no debiera sorprendernos si en un futuro no muy lejano todos ellos, descendientes y cónyuge supérstite o conviviente, fueran llamados de forma conjunta y en el mismo orden, aunque en un porcentaje hereditario diferente.

\section{REFERÊNCIAS}

A. BALBÍN DE UNQUERA, «¿Qué lugar deben ocupar los cónyuges en la sucesión intestada?», en Revista General de Legislación y Jurisprudencia, vol. 37, nº 74, 1889, pp. 745-753

A. D’ORS, El Código de Eurico. Edición. Palingenesia. Índices, Madrid, Boletín Oficial del Estado, 2014, pp. 2 ss.

A. GÓMEZ, Compendio de los comentarios extendidos a las ochenta y tres leyes de Toro, Madrid, 1785, reimpresión facsimilar, Valladolid, Lex Nova, 1981, p. 52.

A. HERNÁNDEZ MORENO - F.M. ECHEVERRÍA SUMMERS, «El régimen de la sucesión intestada en Cataluña», en Economist \& Jurist, Difusión Jurídica y Temas de Actualidad, S.L., (21), $\mathrm{n}^{\circ} .168,2013$, pp. 38 ss.

A. MURILLO VILLAR, «El llamamiento sucesorio a favor del estado en ausencia de herederos: de Roma a la actualidad», en Direito Romano. Poder e Direito, ediçao especial Faculdade de Direito da Universidade de Lisboa, (Coimbra Editora), Lisboa, 2013, pp. 53-70.

premuerto tiene los mismos derechos que la Compilación de Derecho Civil balear prevé al cónyuge viudo". En principio, en Galicia no existe, a pesar de tener competencias en materia de derecho civil, una ley concreta de parejas estables, como sí ocurre en otras comunidades autónomas. No obstante, en la Disposición Adicional Tercera de la Ley 2/2006 de 14 de junio, de Derecho Civil de Galicia se estableció lo siguiente: "1. A los efectos de la aplicación de la presente ley, se equiparan al matrimonio las relaciones maritales mantenidas con intención o vocación de permanencia, con lo que se extienden a los miembros de la pareja los derechos y las obligaciones que la presente ley reconoce a los cónyuges. 2. Tendrán la condición de parejas de hecho las uniones de dos personas mayores de edad, capaces, que convivan con la intención o vocación de permanencia en una relación de afectividad análoga a la conyugal y que la inscriban en el Registro de Parejas de Hecho de Galicia, expresando su voluntad de equiparar sus efectos a los del matrimonio. No pueden constituir parejas de hecho: a) Los familiares en línea recta por consanguinidad o adopción. b) Los colaterales por consanguinidad o adopción hasta el tercer grado. c) Los que estén ligados por matrimonio o formen pareja de hecho debidamente formalizada con otra persona. 3. Los miembros de la unión de hecho podrán establecer válidamente en escritura pública los pactos que estimen convenientes para regir sus relaciones económicas durante la convivencia y para liquidarlas tras su extinción, siempre que no sean contrarios a las leyes, limitativos de la igualdad de derechos que corresponden a cada conviviente o gravemente perjudiciales para cada uno de los mismos. Serán nulos los pactos que contravengan la anterior prohibición.”. 
. «De la importancia de recordar que el derecho es un producto histórico», en Foro Social $\overline{\mathbf{n}^{\circ}}$ 4, Revista de la Escuela de Relaciones Laborales de Burgos, Burgos, 2003, pp. 8-12.

A. NIETO ALONSO, «El régimen de sucesión intestada en Galicia», en Economist \& Jurist, Difusión Jurídica y Temas de Actualidad, S.L., (21), nº. 168, 2013, pp. 32-37.

C. LÓPEZ-RENDO RODRÍGUEZ, «La sucesión intestada en la ley de las Doce Tablas», en Murillo Villar (coord.), Estudios de derecho romano en memoria de Benito $\mathbf{M}^{\mathbf{a}}$ Reimundo Yanes, vol. 1, Burgos, Universidad de Burgos, 2000, pp. 533-568.

Código del Derecho Foral de Aragón, Decreto Legislativo 1/2011, de 22 de marzo, del Gobierno de Aragón.

D. JIMÉNEZ LIÉBANA, «La mejora de la posición del cónyuge viudo en la sucesión intestada del Código Civil», en Herrero Oviedo (coord.), Domínguez Luelmo y García Rubio (dir.), Estudios de derecho de sucesiones: "Liber amicorum" T. F. Torres García, Madrid, LA LEY, 2014, pp. 707 ss.

E. PÉREZ-PUJAZÓN - F.J. RODRÍGUEZ RAMOS, «El régimen de sucesión intestada en España. Régimen general», en Economist \& Jurist, Difusión Jurídica y Temas de Actualidad, S.L., (21), nº 168, 2013, p. 21.

F. BONET RAMÓN, Código civil comentado con su apéndices forales, Madrid, AGUILAR. 1964.

F. GARCÍA GOYENA, Concordancias, motivos y comentarios del Código civil español I, Madrid, 1852, reimpresión, Zaragoza, Cometa S.A., 1974.

F. LLODRÀ GRIMALT, «La sucesión intestada en Baleares», en Gete-Alonso y Calera (dir.), Tratado de derecho de sucesiones. Código civil y normativa civil autonómica: Aragón, Baleares, Cataluña, Galicia, Navarra, País Vasco, vol. 2, Pamplona, Thomson Reuters, 2011, pp. 1713 ss.

. «La sucesión intestada en las Illes Balears», en Cuadrado Iglesias y Núñez Boluda (dir.), Estudios jurídicos en homenaje al profesor Manuel García Amigo, vol. 2, Madrid, La Ley, 2015, pp. 2027 ss.

F. RIVERO HERNÁNDEZ, «Panorama general de la reforma del derecho de familia en el Libro II del Código Civil de Cataluña», en Ginés Castellet, (coord.) La familia del siglo XXI. Algunas novedades del Libro II del Código Civil de Cataluña, Barcelona, BOSCH EDITOR, 2011.

F. SÁNCHEZ ROMÁN, Estudios de Derecho civil, tomo VI, vol. 3, Madrid, SUCESORES DE RIVADENEYRA, 1910.

G. LEÓN PIÑA, «El régimen de sucesión intestada en las Islas Baleares», en Economist \& Jurist, Difusión Jurídica y Temas de Actualidad, S.L., (21), nº. 168, 2013, pp. 48-55.

HEBRERO HERNÁNDEZ, J.A., 2015: El nuevo Derecho Civil Vasco, https://tuguialegal.com/ 2015/07/20/el-nuevo-derecho-civil-vasco/ (última consulta realizada el 9 de febrero de 2017).

GRANADOS DE ASENSIO, D. M ${ }^{\mathrm{a}}, .2015$ : Notas sobre la Ley 5/2015, de 25 de junio, de Derecho Civil Vasco, http://www.notariosyregistradores.com/web/cuadros/ley-de-derecho-civilvasco/. http://www.paisvasco.notariado.org/?do=info\&option=derecho_foral (última consulta realizada el 9 de febrero de 2017).

J. ARIAS RAMOS - J.A. ARIAS BONET, Derecho romano II. Obligaciones. Familia. Sucesiones, $18^{\mathrm{a}}$ ed., $7^{\mathrm{a}}$ reimpresión, Madrid, ed. Revista de Derecho Privado, 1997. 
La influencia del Derecho de Familia en la posición del cónyuge supérstite en el orden de llamamientos en la sucesión $a b$ intestato: evolución histórica

J. ESCRICHE, Diccionario razonado de legislación y jurisprudencia, s.v. "heredero legítimo o ab intestato", $3^{\mathrm{a}}$ ed. corregida y aumentada, Madrid, Librería de la Señora Viuda e Hijos de D. Antonio Calleja, 1847, tomo $2^{\circ}$.

J.F. LASSO GAITE, Crónica de la codificación española. Codificación civil (Génesis e historia del Código), II, Madrid, Ministerio de Justicia, 1970.

M. PÉREZ ESCOLAR, El cónyuge supérstite en la sucesión intestada, Madrid, Dykinson, 2003, pp. 19 ss.

$\mathrm{M}^{\mathrm{a}}$ A. ARQUED SANZ, «El régimen de sucesión intestada en Aragón», en Economist \& Jurist, Difusión Jurídica y Temas de Actualidad, S.L., (21), nº. 168, 2013, pp. 56-61.

$M^{a}$ C. GETE-ALONSO Y CALERA, «La sucesión intestada incorporada al Código Civil de Catalunya (principios-innovaciones)», en El nou dret successori del codi civil de Catalunya: materials de les Quinzenes Jornades de Dret Català a Tossa, Tossa de Mar, 25 i 26 de setembre de 2008, 2009, pp. 209-261.

$M^{a}$ C. BAYOD LÓPEZ, «La sucesión intestada en Aragón», en Gete-Alonso y Calera (dir.), Tratado de derecho de sucesiones. Código civil y normativa civil autonómica: Aragón, Baleares, Cataluña, Galicia, Navarra, País Vasco, vol. 2, Pamplona, Thomson Reuters, 2011, pp. 1611 ss.

Ma CÁRCABA FERNÁNDEZ, «Derechos del cónyuge viudo en la sucesión intestada tras la reforma del Código Civil operada por Ley 11/1981 de 13 de mayo», en La Ley: Revista jurídica española de doctrina, jurisprudencia y bibliografía, no 1, 1986, p. 1177 nts.1 y 2. E. De La Iglesia Prados, Análisis de la sucesión intestada, Valencia, Tirant lo Blanch, 2012, pp. 212 ss. nt.1. pp. 57 ss.

Los derechos sucesorios del cónyuge viudo, Oviedo, Universidad de Oviedo, 1993,

$\mathrm{M}^{\mathrm{a}}$ YSÀS SOLANES, «La sucesión intestada en Cataluña», en Gete-Alonso y Calera, (dir.), Tratado de derecho de sucesiones. Código civil y normativa civil autonómica: Aragón, Baleares, Cataluña, Galicia, Navarra, País Vasco, vol. 2, Pamplona, Thomson Reuters, 2011, pp. 1681 ss.

. «La sucesión intestada en Cataluña: (Estado de la cuestión)», Libro-Homenaje al profesor Manuel Amorós Guardiola, vol. 2, Madrid, CENTRO DE ESTUDIOS, 2006, pp. 2051 ss.

PÉREZ ESCOLAR, «Sucesión intestada del cónyuge supérstite», cit., pp. 2770.

PÉREZ ESCOLAR, El cónyuge supérstite en la sucesión intestada, cit., p. 27 ss.

S. CÁMARA LAPUENTE, «¿Derecho europeo de sucesiones? Un apunte», en Cámara Lapuente, (coord.), Derecho Privado Europeo, Madrid, Colex, 2003.

S. DE LLAMAS Y MOLINA, Comentario crítico-jurídico-literal a las ochenta y tres Leyes de Toro, $2^{a}$ ed., Madrid, Compañía de Impresores y Libreros del Reino, 1852, p. 67.

S. LLEBARÍA SAMPER, «La sucesión intestada del conviviente homosexual: Comentario a y desde la STSJ Cataluña, 9.3.2009», en InDret: Revista para el Análisis del Derecho, no . 3, 2009.

S. NAVAS NAVARRO, «La sucesión intestada de la Generalidad de Cataluña», Anuario de Derecho Civil, vol. 55, n⿳⺈ 3, 2002, pp. 1058 ss. 
S. VALVERDE MARTÍNEZ, «La unificación del derecho sucesorio europeo», en Economist \& Jurist, Difusión Jurídica y Temas de Actualidad, S.L., (21), nº. 168, 2013.

W. PINTENS, «Die Europäisierung des Erbrechts», en Zeitschrift für Europäisches Privatrecht (ZEuP) 3, 2001.

Recebido em: 28 set. 2017.

Aceito em: 30 nov. 2017. 